\title{
GTP-SENSITIVE PHOSPHORYLATION OF PROTEINS IN A POSTMITOCHONDRIAL SUPERNATANT FROM RAT BRAINSTEM AFFECTED BY ACTH A $_{1-24}$
}

\author{
A. M. A. Van Dijk, ${ }^{1}$ G. Benítez King ${ }^{2}$ P. Schotman, \\ AND W. H. Gispen \\ Division of Molecular Neurobiology \\ Institute of Molecular Biology \\ Laboratory for Physiological Chemistry and \\ Rudolf Magnus Institute for Pharmacology \\ State University of Utrecht \\ Padualaan 8, 3508 TB Utrecht, The Netherlands
}

Accepted April 3, 1981

The effect of $\mathrm{ACTH}_{1-24}$ and cyclic nucleotides on the endogenous phosphorylation of proteins from a postmitochondrial supernatant from rat brainstem was investigated in the presence and absence of GTP. Phosphorylation and its modulation by these compounds were studied in vitro by incorporation of labeled phosphate from $\left[\gamma-{ }^{32} \mathrm{P}\right] \mathrm{ATP}$ added to the incubation mixture. Phosphoproteins were subsequently analyzed by autoradiography after one- and two-dimensional separation. Eight ACTH-sensitive phosphoproteins of molecular weights 75 (IEP 4.0), 67, 64, 50 (IEP 4.7), 47 (IEP 4.8), 38, 34, and $24 \mathrm{~K}$ were found. The effects of ACTH on phosphorylation were mainly inhibitory, and the affected protein bands did not coincide with the phosphoproteins sensitive to cyclic AMP and cyclic GMP. Phosphorylation of those phosphoprotein bands and its ACTH sensitivity appeared to be highly sensitive to GTP. It is suggested that the activity of protein kinases involved in hormone-sensitive phosphorylation in a postmitochondrial rat brainstem fraction is regulated by GTP-dependent mechanisms.

' Present address: Hoffmann-La Roche, Dept. of Pharmaceutical Research, Grenzacherstr. 124, CH-4002 Basle, Switzerland.

2 Present address: Dept. of Cellular Biology, Centro de Investigación del I.P.N., Apartado 14-740, Mexico 14, DF Mexico. 


\section{INTRODUCTION}

Ribonucleic acid and protein synthesis in the central nervous system are affected by ACTH-like peptides (1-3), and their activity in behavioral processes has been firmly established (4). Cell-free protein synthesis in a postmitochondrial supernatant from rat brainstem could be modulated by $\mathrm{ACTH}_{1-24}$ and related peptides (5). The similarity in structure-activity relationship between effects of ACTH exerted in vivo and on cell-free protein synthesis $(3,5)$ might indicate a role for these peptides after internalization. Neurochemical actions of ACTH-like peptides in the rat brain are also found at the level of adenylate cyclase activity and phosphorylation of membrane proteins (6-8).

Phosphorylation of proteins associated with the ribosomal system has been implicated in the regulation of the rate of protein synthesis in rabbit reticulocytes $(9-11)$, rat liver $(12,13)$ and bovine adrenal cortex $(14,15)$. With respect to the central nervous system, it was demonstrated that several ribosomal proteins were phosphorylated in rat cerebral cortex in vitro $(16,17)$ and in vivo $(18)$. Some of them were affected by cyclic AMP (17).

The question arises whether the effects of ACTH on cell-free protein synthesis (5) may arise from changes in phosphorylation of ribosomal proteins. In this initial study we report the effects of ACTH on protein phosphorylation in a postmitochondrial supernatant from rat brainstem in comparison with the effects of cyclic nucleotides. Since protein synthesis requires GTP $(5,19,20)$, the effect of the presence of GTP during incubation was also evaluated.

\section{EXPERIMENTAL PROCEDURE}

Chemicals. Acrylamide and methylenebisacrylamide (Serva, Heidelberg, West Germany), fast green (Sigma, St. Louis, Missouri), sodium dodecylsulfate (BDH, Poole, England), glycin (Merck, Darmstadt, West Germany), standard proteins (Pharmacia, Uppsala, Sweden). Cyclic AMP and cyclic GMP (Sigma, St. Louis, Missouri), synthetic ACTH A $_{1-24}$ (130 units/mg), kindly provided by Dr. H. M. Greven (Organon Int. BV, Oss, The Netherlands), $\left[\gamma-{ }^{32} \mathrm{P}\right]$ ATP $(3000 \mathrm{Ci} / \mathrm{mmol})$ (The Radiochemical Centre, Amersham, England).

Preparation of Postmitochondrial Supernatant from Rat Brainstem. The procedure was identical to the one designed for the measurement of cell-free protein synthesis (5). All glassware was sterilized in order to minimize nucleolytic and proteolytic activity. Brainstems were dissected from male Wistar rats weighting 140-160 g (21). Each brainstem was homogenized $(1: 2, \mathrm{w} / \mathrm{v})$ in an ice-cold $50 \mathrm{mM}$ Tris- $\mathrm{HCl}$ buffered solution $(\mathrm{pH} 7.6)$, containing $25 \mathrm{mM}$ sucrose and $\mathrm{KCl}$, and $2 \mathrm{mM} \mathrm{MgCl}$ (homogenization buffer), by pottering ten times in a Potter-Elvehjem homogenizer (clearance $0.250 \mathrm{~mm}$ at $0^{\circ} \mathrm{C}$ ) at $1450 \mathrm{rpm}$. The homogenate was centrifuged in a Sorvall SS-34 at $1000 \mathrm{~g}$ for $10 \mathrm{~min}$ to remove cell nuclei and debris. 
The resulting supernatant was centrifuged at $20,000 \mathrm{~g}$ for $20 \mathrm{~min}$ to obtain a postmitochondrial supernatant fraction. Such a supernatant contained $10 \mathrm{mg}$ protein $/ \mathrm{ml}$ as determined by the method of Lowry et al. (22).

Phosphorylation Assay. The procedure is a modification of the one described by Zwiers et al. (6). Routinely, assays were carried out at $30^{\circ} \mathrm{C}$ in polypropylene tubes in a total volume of $50 \mu \mathrm{l}$. An aliquot of $10 \mu \mathrm{l}$ of postmitochondrial supernatant (undiluted or diluted 1:1 with homogenization buffer) was mixed with $30 \mu \mathrm{l}$ of phosphorylation buffer such that a final concentration of $50 \mathrm{mM}$ Tris- $\mathrm{HCl}, \mathrm{pH} 7.6,100 \mathrm{mM} \mathrm{KCl}, 12 \mathrm{mM} \mathrm{MgCl}_{2}, 6 \mathrm{mM} \beta$-mercaptoethanol, and $0.1 \mathrm{mM}$ GTP (unless otherwise stated) was obtained. The reaction mixture was then preincubated for $1 \mathrm{~min}$ at which time $5 \mu \mathrm{l}$ of phosphorylation buffer or buffer containing test substances were added. Incubation was continued for $1 \mathrm{~min}$ and incorporation of labeled phosphate was initiated by addition of $5 \mu \mathrm{Ci}\left[\gamma^{-}{ }^{32} \mathrm{P}\right] \mathrm{ATP}$ in $5 \mu$ l phosphorylation buffer. The reaction was stopped after $15 \mathrm{sec}$ either in liquid nitrogen for two-dimensional separation or by adding $25 \mu \mathrm{l}$ stopmix $(187.5 \mathrm{mM}$ Tris- $\mathrm{HCl}, \mathrm{pH} 6.8,6 \% \mathrm{SDS}, 30 \%$ glycerol, $0.003 \%$ bromophenol blue, and $15 \% 2$-mercaptoethanol) in case of one-dimensional separation.

One-Dimensional Separation. Samples were subjected to polyacrylamide gel electrophoresis (PAGE) in the presence of sodium dodecylsulfate (SDS), according to the method of Zwiers et al. (6) with minor modifications. The composition of the electrophoresis buffer

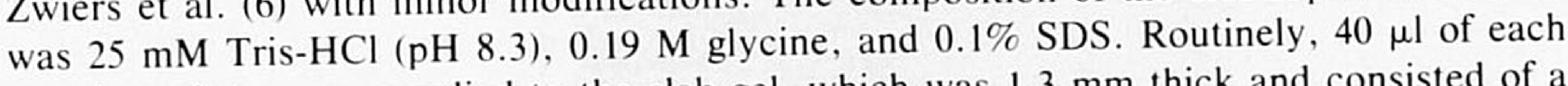
reaction mixture was applied to the slab gel, which was $1.3 \mathrm{~mm}$ thick and consisted of a $12 \%$ running gel of $9 \mathrm{~cm}$ and a $3 \%$ stacking gel of $2 \mathrm{~cm}$. Electrophoresis was carried out at a constant current of $40 \mathrm{~mA}$ at room temperature until the front reached the bottom of the gel $\left(2-2 \frac{1}{2} \mathrm{hr}\right)$. Gels were stained with $0.1 \%$ fast green solution for $5-10 \mathrm{~min}$ and subsequently destained for $24 \mathrm{hr}$ with the same solvent (methanol-acetic acid-water, $4: 1: 6, \mathrm{v} / \mathrm{v}$ ).

After drying, autoradiograms were obtained after exposure of Kodak Royal X-Omat Xray film to the gel for a time period which allowed a linear relationship between radioactivity and grain density per band. The autoradiograms were scanned by densitometry at $550 \mathrm{~nm}$ using a Zeiss M4QII spectrophotometer with a KM-3 chromatogram attachment. A mixture of standard proteins for estimation of the molecular weights was dissolved in phosphorylation buffer and treated with stopmix $(2: 1, \mathrm{v} / \mathrm{v})$, identical to the samples. Estimation of the molecular weights of the proteins was accomplished by reference to a semilogarithmic plot of molecular weights and $R_{f}$ values, obtained with the following standards: phosphorylase b $(92.5 \mathrm{~K})$, albumin $(67 \mathrm{~K})$, catalase $(60 \mathrm{~K})$, ovalbumin $(43 \mathrm{~K})$, lactate dehydrogenase $(36 \mathrm{~K})$, carbonic anhydrase $(30 \mathrm{~K})$, trypsin inhibitor $(20 \mathrm{~K})$, and $\alpha$-lactalbumin $(14.4 \mathrm{~K})$.

Two-Dimensional Separation. Samples were subjected to two-dimensional separation by isoelectric focusing (IEF) and SDS-PAGE. This involved separation of proteins according to isoelectric point (IEP) in the first dimension and to molecular weight in the second dimension. IEF was performed according to the method of O'Farrell (23) with slight modifications. The dimension of the gel was $11 \mathrm{~cm} \times 15 \mathrm{~cm} \times 1.3 \mathrm{~mm}$ and the final concentrations in the gel solution were: $8.5 \mathrm{M}$ urea, $0.5 \%$ Triton $\mathrm{X}-100,5 \%$ polyacrylamide, $10 \%$ glycerol, $2.5 \%$ ampholines (range $\mathrm{pH} 3.5-9.5$ ). Polymerization of the gel was initiated by addition of riboflavin $(0.1 \mathrm{mg} / 100 \mathrm{ml}$ gel mixture $)$ and completed within $2 \mathrm{hr}$ by illumination under fluorescent lamps at room temperature. The gels were preequilibrated successively at 200 $\mathrm{V}$ for $15 \mathrm{~min}$, at $300 \mathrm{~V}$ for $30 \mathrm{~min}$, and at $400 \mathrm{~V}$ for $120 \mathrm{~min}$. The phosphorylated samples from the cell-free brainstem homogenate $(2 \mathrm{mg}$ protein $/ \mathrm{ml})$ were mixed with urea and Triton solution up to final concentrations of $8.5 \mathrm{M}$ and $0.5 \%$, respectively. After addition of $10 \mu \mathrm{l}$ of a mixture of ampholines and sucrose to final concentrations of 1 and $5 \%(\mathrm{w} / \mathrm{v})$, respectively, the samples were placed at the cathode and were run at $400 \mathrm{~V}$ for $18 \mathrm{hr}$ and at 800 $\mathrm{V}$ for $1.5 \mathrm{hr}$ to complete isoelectric focusing. For each applied sample a strip was cut out 
of the slab gel of about $1 \mathrm{~cm}$ and mounted horizontally on top of an SDS-polyacrylamide slab gel. Routinely, one track was cut into 10 sections and subsequently extracted with xaqua bidestillata to determine the $\mathrm{pH}$ gradient from cathode to anode. The strips were covered with a solution of $0.5 \%$ agarose, $62.5 \mathrm{mM}$ Tris- $\mathrm{HCl}$ ( $\mathrm{pH} 6.5$ ), $2 \%$ SDS, $10 \%$ glycerol, $0.01 \%$ bromophenol blue, and $5 \%$ 2-mercaptoethanol. The bromophenol blue served as tracking dye. Samples, phosphorylated under the same conditions, treated with urea-Triton but not subjected to IEF were run on both sides for determination of the molecular weights in the second dimension. The proteins were run through the stacking gel with a current of $15 \mathrm{~mA} / \mathrm{gel}$. When the tracking dye reached the running gel, the current was increased to 40 $\mathrm{mA} / \mathrm{gel}$. The remaining procedure was identical to the one described for the samples applied on SDS-polyacrylamide gels as first dimensions.

Calculations and Statistics. Comparisons were made only between samples of one gel. In some experiments phosphorylated protein spots were individually cut out from the twodimensional slab gel and radioactivity was determined by liquid scintillation counting. Quantification of the ${ }^{32} \mathrm{P}$ radioactivity was obtained by measuring peak heights above the background (24-26). Statistical analyses were performed using two-tailed nonpaired Student's $t$ tests at a significance level of $P<0.05$.

\section{RESULTS}

A postmitochondrial supernatant from rat brainstem was prepared (see Experimental Procedure) in a way that preserved sensitivity of cell-free protein synthesis to ACTH and cyclic AMP (5). The phosphorylation in this cell-free system was studied under conditions (see Experimental Procedure) suitable to measure protein kinase activity at the membrane level and its sensitivity to ACTH and cyclic nucleotides (6).

\section{One-Dimensional Separation}

Phosphoprotein Patterns. Figure 1a shows the protein pattern of the postmitochondrial supernatant from brainstem after fast green staining. The autoradiograms (Figure 1b) revealed the presence of many phosphoproteins. Apart from the $54 \mathrm{~K}$ band, the labeled phosphoprotein bands did not coincide with the bands stained with fast green.

Sensitivity to GTP. The phosphorylation of 12 of the phosphoprotein bands appeared to be sensitive to GTP as can be seen from Figures 1b, $1 \mathrm{c}$, and 2 . Some of the bands $(17,20,47,67$, and $75 \mathrm{~K})$ showed an increase of the level of phosphorylation at a higher GTP concentration $\left(10^{-4} \mathrm{M}\right)$. Phosphorylation of the bands at $24,34,38,40,50,58$, and $64 \mathrm{~K}$ was decreased at high concentrations of GTP $\left(>10^{-5} \mathrm{M}\right)$. Two phospho bands showed an almost complete GTP-dependency, the $58 \mathrm{~K}$ being only visible at GTP concentrations lower than $10^{-5} \mathrm{M}$ and the $67 \mathrm{~K}$ only at a GTP concentration of $10^{-4} \mathrm{M}$.

Sensitivity to $A C T H_{1-24}$. The influence of $\mathrm{ACTH}_{1-24}\left(10^{-4} \mathrm{M}\right)$ was 


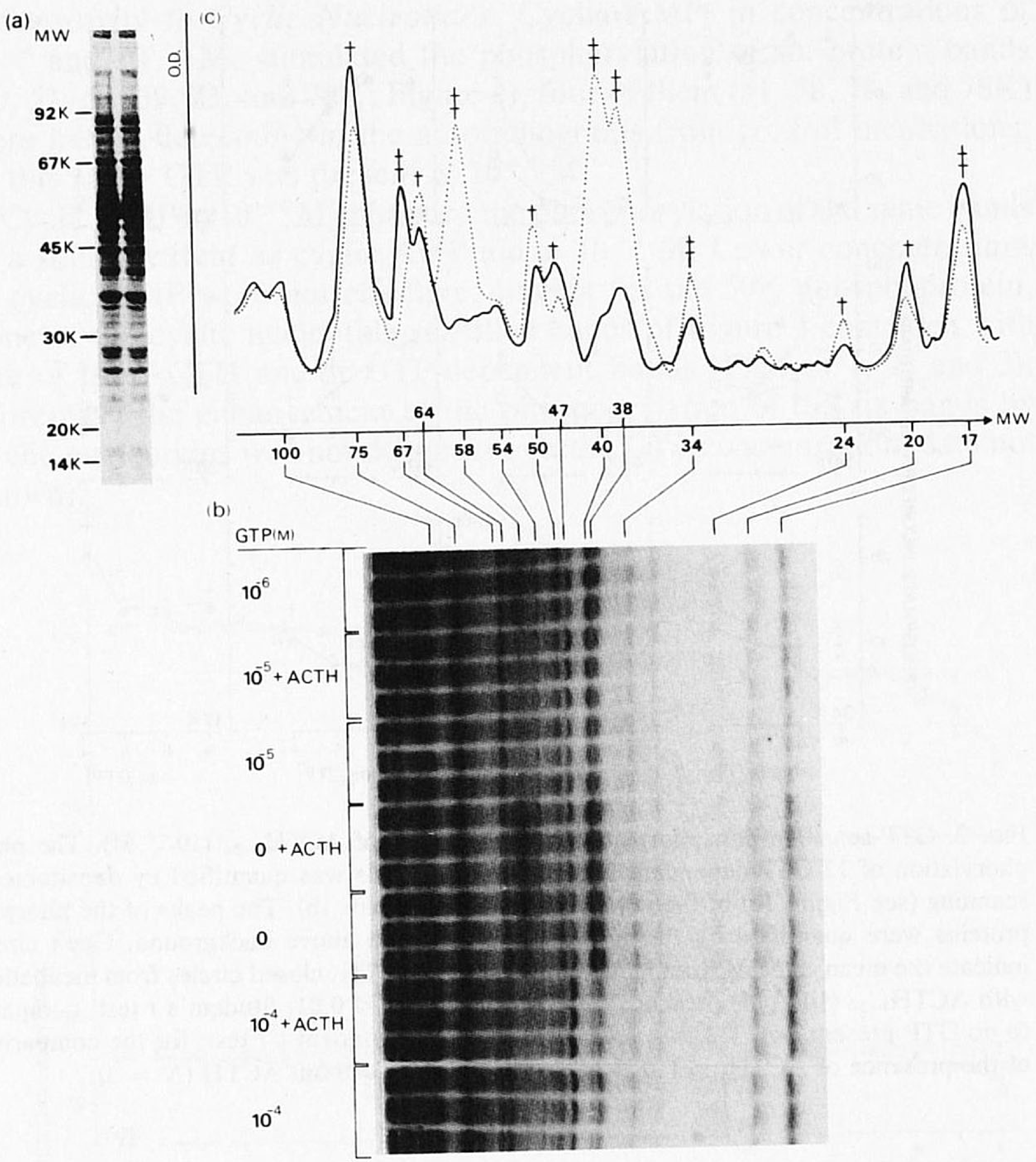

FIG. 1. (a) One-dimensional protein pattern after fast green staining. The proteins of a postmitochondrial supernatant from rat brainstem were separated by electrophoresis on SDS-polyacrylamide gels according to their molecular weights. Molecular weights, indicated on the left side, were obtained from a mixture of pure protein standards, which was run along with the brain proteins under similar conditions. (b) Autoradiograms obtained from the same gels indicating the positions of ${ }^{32} \mathrm{P}$-labeled phosphoproteins. The different conditions during phosphorylation were run in triplicate as indicated along the tracks. ACTH was added as $\mathrm{ACTH}_{1-24}\left(10^{-4} \mathrm{M}\right)$. The $24 \mathrm{~K}$ phospho band was quantified from an autoradiogram exposed about ten times longer to the radioactive gel. (c) Densitometric scans obtained from two tracks of the autoradiogram. The solid line represents phosphorylation in the presence of GTP $\left(10^{-4} \mathrm{M}\right)$, the dotted line in the absence of GTP. OD, optical density; MW, molecular weight; $\dagger 2 P<0.05 \ddagger 2 P<0.01$ (Student's $t$ test, $N=3$ ). 


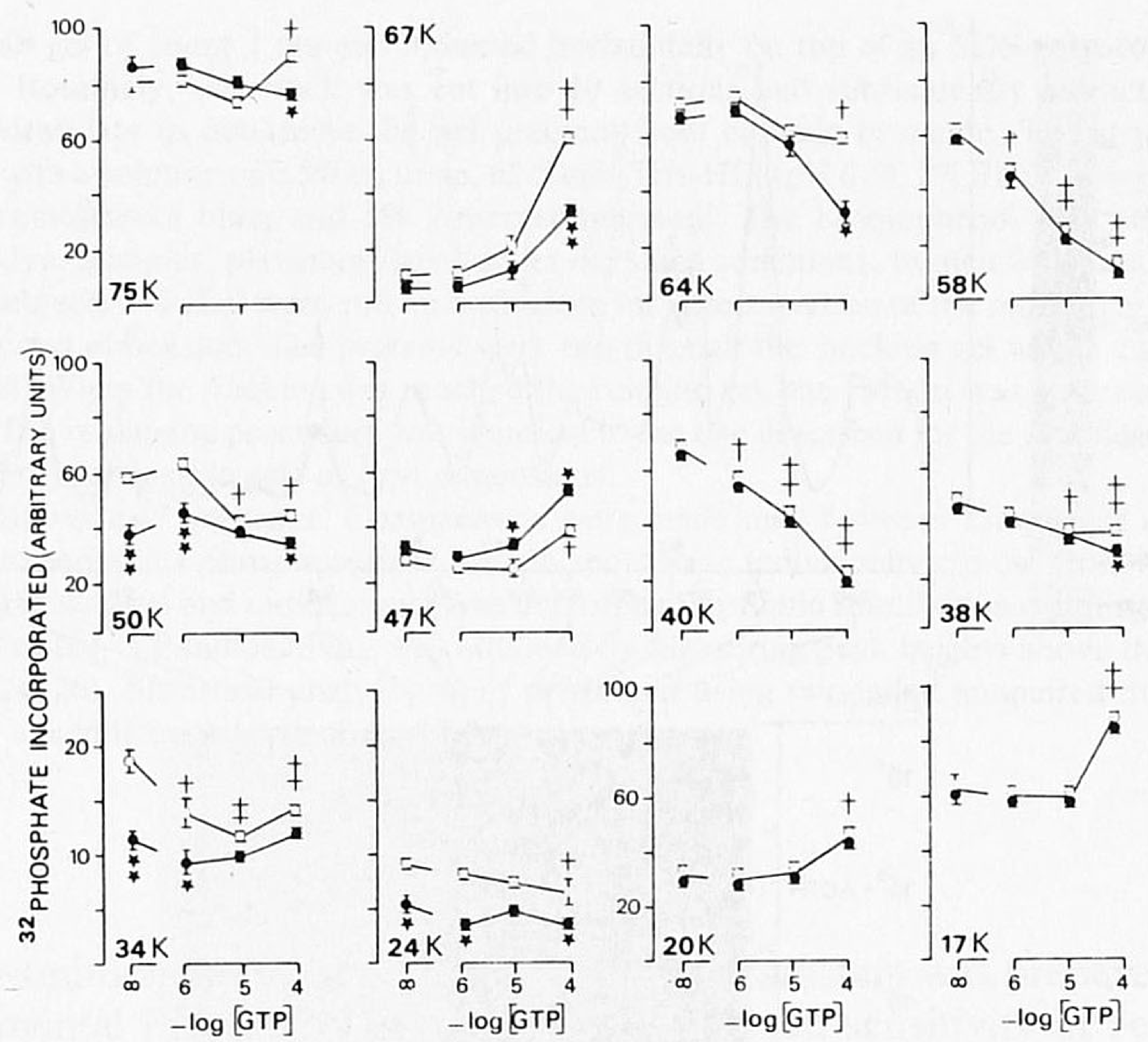

FIG. 2. GTP-sensitive phosphorylation and the effect of $\mathrm{ACTH}_{1-24}\left(10^{-4} \mathrm{M}\right)$. The phosphorylation of 12 GTP-dependent phosphoprotein bands was quantified by densitometric scanning (see Figure 1c) of the autoradiogram (see Figure 1b). The peaks of the phosphoproteins were quantified by taking peak height in $\mathrm{mm}$ above background. Open circles indicate the mean \pm SEM from incubations without $\mathrm{ACTH}$, closed circles from incubations with $\mathrm{ACTH}_{1-24}\left(10^{-4} \mathrm{M}\right)$ present. $\dagger 2 P<0.05 ; \ddagger 2 P<0.01$; Student's $t$ test, compared to no GTP present $(\infty) ;{ }^{*} 2 P<0.05 ;{ }^{* *} 2 P<0.01$, Student's $t$ test, for the comparison of the presence of $\mathrm{ACTH}_{1-24}\left(10^{-4} \mathrm{M}\right)$ to the controls without ACTH $(N=3)$.

measured at various GTP concentrations (Figure $1 \mathrm{~b}$ and 2). The effect of ACTH on the phosphorylation was mainly inhibitory (bands $24,34,38$, $50,64,67$, and $75 \mathrm{~K}$ ); only the phosphorylation of the $47 \mathrm{~K}$ band was stimulated. All ACTH-sensitive phosphoprotein bands were GTP-dependent phosphorylated. In case of the 24,34 , and $50 \mathrm{~K}$ bands, both phosphorylation and its decrease by $\mathrm{ACTH}_{1-24}\left(10^{-4} \mathrm{M}\right)$ were maximal at low GTP concentrations $\left(<10^{-6} \mathrm{M}\right)$. In case of the $38,47,64$, and $75 \mathrm{~K}$ bands, phosphorylation and its sensitivity to ACTH were maximal at high GTP concentrations $\left(>10^{-5} \mathrm{M}\right)$.

The ACTH sensitivity at a high GTP concentration was further investigated using a concentration range from $10^{-4}$ to $10^{-9} \mathrm{M}$ of $\mathrm{ACTH}_{1-24}$ (Figure 3). It appeared that the concentration of $10^{-4} \mathrm{M} \mathrm{ACTH}_{1-24}$ was most effective on phosphorylation of all ACTH-sensitive bands. 
Sensitivity to Cyclic Nucleotides. Cyclic AMP, in concentrations of $10^{-4}$ and $10^{-5} \mathrm{M}$, stimulated the phosphorylation of six protein bands $(50,51,54,58,73$, and $78 \mathrm{~K}$; Figure 4$)$, four of them $(51,58,73$, and $78 \mathrm{~K})$ were hardly detectable in the autoradiograms from control incubations. In this study GTP was present at $10^{-4} \mathrm{M}$.

Cyclic GMP at $10^{-4} \mathrm{M}$ enhanced the phosphorylation of the same bands to a similar extent as cyclic AMP did at $10^{-5} \mathrm{M}$. Lower concentrations of cyclic GMP were not effective. Except for the $50 \mathrm{~K}$ phosphoprotein, none of the cyclic nucleotide-sensitive bands of Figure 4 coincided with one of the ACTH and/or GTP-dependent bands (Figures 1, 2, and 3). Moreover, the enhancement of the phosphorylation of the six bands by cyclic nucleotides was not dependent on the GTP concentration (data not shown).
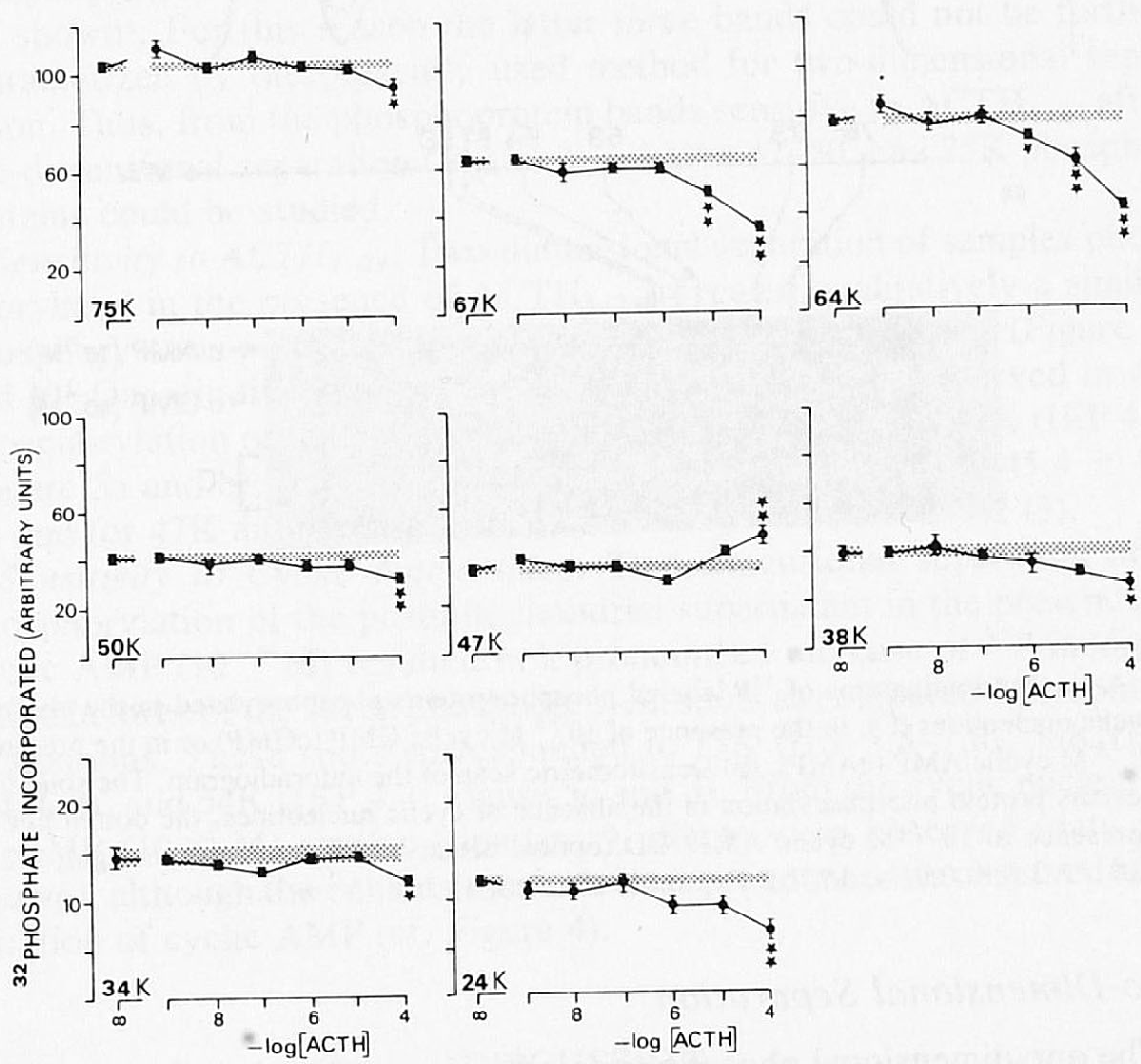

FIG. 3. The effect of $\mathrm{ACTH}_{1-24}$ in concentrations ranging from $10^{-4}$ to $10^{-9} \mathrm{M}$ on the phosphorylation of eight phosphoprotein bands. The peaks of these phosphoproteins on corresponding densitometric scans were quantified by taking peak height in $\mathrm{mm}$ above the background. Values are depicted as the mean $\pm \operatorname{SEM}(N=3)$. Values of control incubations

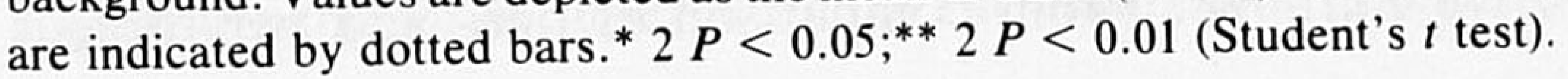




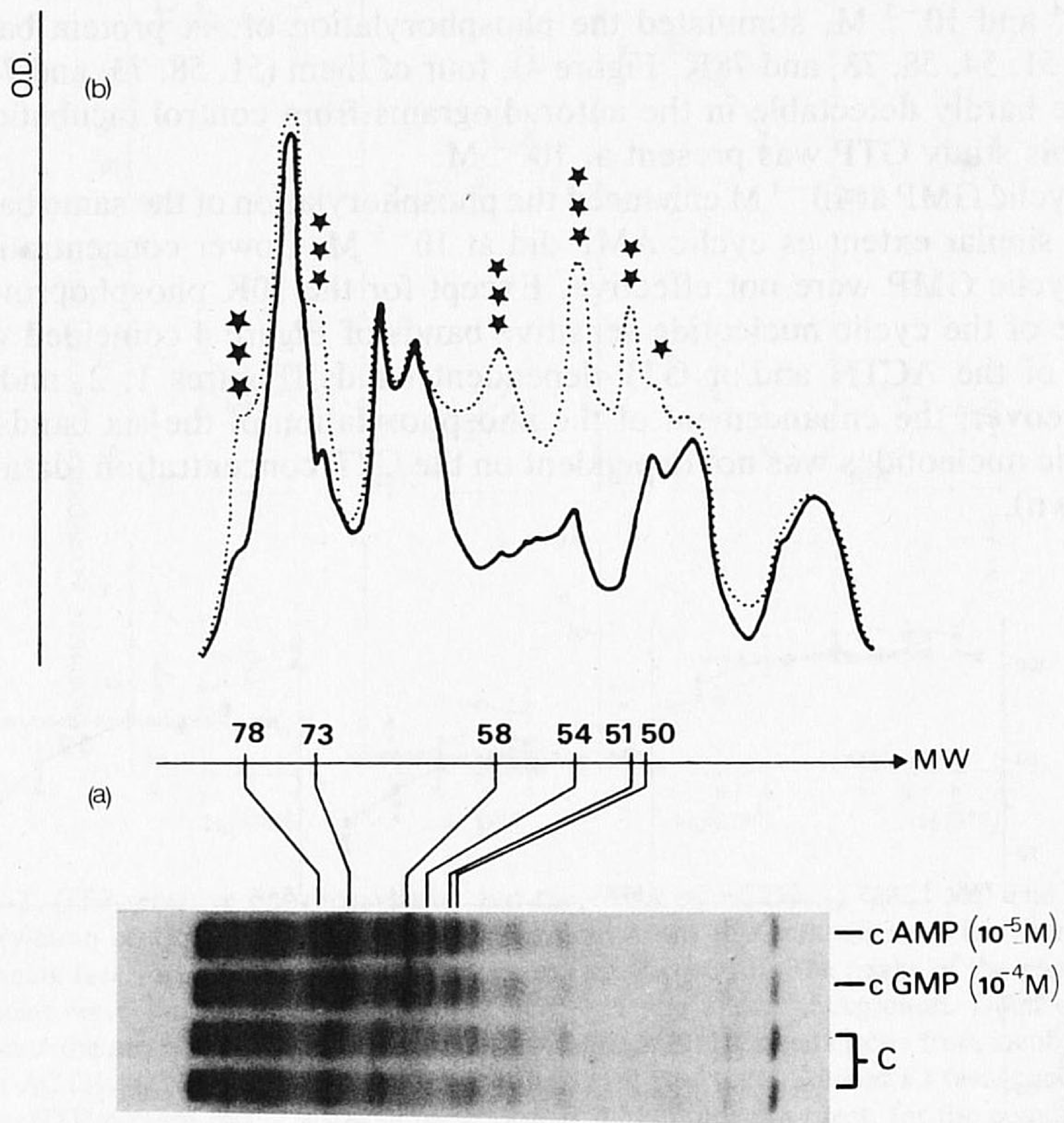

Fig. 4. (a) Autoradiograms of ${ }^{32} \mathrm{P}$-labeled phosphoproteins phosphorylated in the absence of cyclic nucleotides (C), in the presence of $10^{-4} \mathrm{M}$ cyclic GMP (cGMP) or in the presence of $10^{-5} \mathrm{M}$ cyclic AMP (cAMP). (b) Densitometric scan of the autoradiogram. The solid line represents protein phosphorylation in the absence of cyclic nucleotides, the dotted line in the presence of $10^{-5} \mathrm{M}$ cyclic AMP. OD, optical density; MW, molecular weight; ${ }^{*} 2 P$ $<0.05$; ** $2 P<0.01$ and ${ }^{* * *} 2 P<0.001$ (Student's $t$ test, $N=3$ ).

\section{Two-Dimensional Separation}

The one-dimensional phosphoprotein bands were further characterized according to their IEP's after two-dimensional separation (see experimental procedures) and subsequently in terms of sensitivity to $\mathrm{ACTH}_{1-24}$ and cyclic nucleotides.

Phosphoprotein Patterns. From comparison of one- and two-dimen- 
sional autoradiograms of Figures 1 and 5, respectively, seven phosphoprotein spots could be clearly identified. The phosphoprotein $75 \mathrm{~K}$ consisted of one single phosphoprotein at IEP 4.0. Two other phosphoproteins with molecular weights of 47 and $50 \mathrm{~K}$ were found to be acidic with an IEP within the range of 4.6-4.9. The $58 \mathrm{~K}$ band was split into two clusters of spots with IEP of 5.4-6.8 and 4.8-5.1, respectively. The $73 \mathrm{~K}$ phosphoprotein covered an IEP range of 5.8-7.0. The 54K, which was the only phosphoprotein band that coincided with a stained protein band after one-dimensional separation (Figure 1), appeared to consist of one phosphoprotein with an IEP of 4.7.

The use of urea-Triton in the two-dimensional separation was evaluated by comparison between phosphorylation patterns after one-dimensional separation of samples treated with and without urea-Triton. Such a treatment induced enrichment of the $73 \mathrm{~K}$ phosphoprotein band, whereas the phosphoprotein bands 100,67 , and $24 \mathrm{~K}$ were no longer detectable (data not shown). For this reason the latter three bands could not be further characterized by the presently used method for two-dimensional separation. Thus, from the phosphoprotein bands sensitive to $\mathrm{ACTH}_{1-24}$ after one-dimensional separation (Figure 2 ) only the 47,50 , and $75 \mathrm{~K}$ phosphoproteins could be studied.

Sensitivity to ACTH ${ }_{1-24}$. Two-dimensional separation of samples phosphorylated in the presence of $\mathrm{ACTH}_{1-24}$ revealed qualitatively a similar phosphorylation pattern as compared with control incubations (Figure 5a and b). Quantitative changes by ACTH $\left(10^{-4} \mathrm{M}\right)$ were observed in the phosphorylation of the phosphoproteins $75 \mathrm{~K}$ (IEP 4.7) and 47K (IEP 4.8) (Figure $5 \mathrm{a}$ and $\mathrm{b}$ ); for $75 \mathrm{~K}$ a decrease from $83.3 \pm 2.2$ (3) to $45.4 \pm 1.4$ (3) and for $47 \mathrm{~K}$ an increase from $32.5 \pm 0.9$ (3) to $36.1 \pm 1.2$ (3).

Sensitivity to Cyclic Nucleotides. Two-dimensional separation after phosphorylation of the postmitochondrial supernatant in the presence of cyclic AMP $\left(10^{-5} \mathrm{M}\right)$ resulted in a pronounced increase of ${ }^{32} \mathrm{P}$ incorporation in three of the seven phosphoprotein spots as compared with control incubations. These spots corresponded to 73K (IEP 5.8-7.0), 58K (IEP 5.4-6.8), and 54K (IEP 4.7; Figure 5c and d). From the cyclic nucleotide of GMP $\left(10^{-4} \mathrm{M}\right)$ similar stimulatory effects were observed (data not shown), although the enhancement was less pronounced as observed after addition of cyclic AMP (cf. Figure 4).

\section{DISCUSSION}

In the present study we investigated phosphorylation of phosphoproteins and their sensitivity to $\mathrm{ACTH}_{1-24}$, cyclic nucleotides, and GTP in a postmitochondrial supernatant of rat brainstem. Phosphoproteins were 


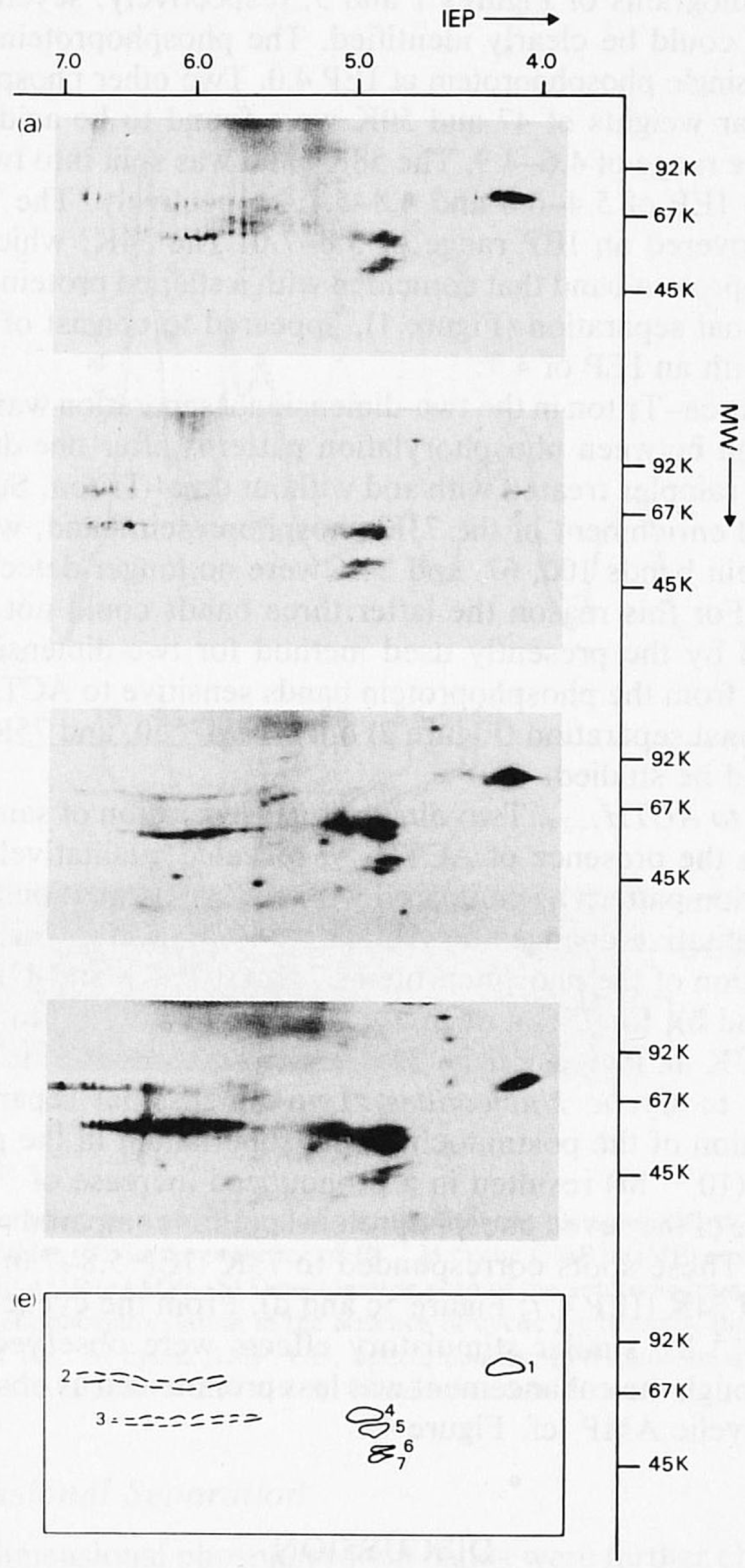

FIG. 5. Autoradiograms of ${ }^{32} \mathrm{P}$-labeled phosphoproteins after two-dimensional separation. Phosphoproteins were separated in the first dimension according to their isoelectric point 
identified according to molecular weight by one-dimensional separation (Figure 1) and some according to isoelectric point and molecular weight by two-dimensional separation (Figure 5 ). In general, with the presently available techniques of two-dimensional separation, not all SDS-PAGE bands could be characterized with respect to their IEPs (Figure 5) (23, 29). Since no proteins remained at the top of the IEF gel, the disappearance of these bands might be due to urea-Triton treatment and/or the isoelectric focusing.

Except for the 54K (IEP 4.7) phosphoprotein, no correlation was found between the pattern of the stained proteins and that of the phosphoproteins. Hence, almost all phosphoproteins are minor components in the postmitochondrial supernatant from rat brainstem. According to its molecular weight and major appearance, the $54 \mathrm{~K}$ protein might be identical to the phosphorylated subunit of tubulin $(27,28)$. With respect to its IEP (4.7), a comparison with the literature $(29,30)$ is obscured by the fact that in these studies isoelectric focusing has been performed on SDS-treated proteins. As the authors stated themselves (29), such treatment prevents determination of the original IEPs of the proteins.

The use of a postmitochondrial supernatant from rat brainstem under conditions optimized for protein synthesis and sensitivity to peptides implicated the presence of GTP (5). However, phosphorylation of phosphoproteins in this system appeared to be highly sensitive to GTP (Figure $1 \mathrm{~b}, 1 \mathrm{c}$, and 2). A decrease in ${ }^{32} \mathrm{P}$ incorporation induced by GTP as was found for the phosphoprotein bands at $24,34,38,40,50,58$, and $64 \mathrm{~K}$ (Figure 2) may result from a competition of the unlabeled GTP with the labeled ATP as substrate for phosphorylation. However, when unlabeled ATP was added to the incubation with $\left[\gamma^{-32} \mathrm{P}\right] \mathrm{ATP}$, labeling of all phosphoproteins was reduced (data not shown). The specific competition of GTP with certain bands therefore, may be indicative for the presence of type b-like protein kinases (31). Protein kinases which use GTP as well as ATP as substrate have also been shown in rabbit reticulocytes $(9,32)$. Enhancement of phosphorylation by GTP, as was shown by the phospho bands at 17, 20, 47, 67, and 75K (Figure 2), suggests the involvement of protein kinases whose activity partially or fully $(67 \mathrm{~K})$ depends on GTP in a role other than that of substrate.

(IEP) and in the second dimension according to their molecular weight (MW). The results of two separate experiments a, b and c, d are shown. (a) Phosphorylation without $\mathrm{ACTH}_{1-24}$. (b) Phosphorylation in the presence of $10^{-4} \mathrm{M} \mathrm{ACTH}_{1-24}$. (c) Phosphorylation without cyclic AMP. (d) Phosphorylation in the presence of $10^{-5} \mathrm{M}$ cyclic AMP. (e) Picture of seven clearly identified phosphoproteins. 1: 75K (IEP 4.7); 2: 73K (IEP 5.8-7.0); 3: 58K (IEP 5.4-6.8); 4: 58K (IEP 4.8-5.1); 5: 54K (IEP 4.7); 6: 50K (IEP 4.7); 7: 47K (IEP 4.8). 
$\mathrm{ACTH}_{1-24}$ at a concentration of $10^{-4} \mathrm{M}$ affected the GTP-dependent phosphorylation of eight phosphoprotein bands (Figure 2; 24, 34, 38, 47, $50,64,67$, and $75 \mathrm{~K}$ ). Interestingly, the highest sensitivity to $\mathrm{ACTH}_{1-24}$ $\left(10^{-4} \mathrm{M}\right)$ was observed at the GTP concentration that also resulted in the maximum phosphorylation level of the particular bands (Figure 2). This might suggest that ACTH interferes with the GTP-site(s) for phosphorylation.

Although a great deal of work was done on characterization of soluble protein kinase activities in combination with exogenous substrates, much less is known of their endogenous substrates (33). The two ACTH-sensitive phosphoproteins of $47 \mathrm{~K}$ and $50 \mathrm{~K}$ (IEP 4.6-4.9) are in the same molecular weight range as a $46 \mathrm{~K}$ cytoplasmic phosphoprotein in hepatocytes which appeared to be insulin sensitive (34). With respect to the occurrence of the ACTH-sensitive phosphoprotein $24 \mathrm{~K}$, it is interesting that in adrenal cortical cells, besides a cytoplasmic $150 \mathrm{~K}$ phosphoprotein, phosphorylation of a $16 \mathrm{~K}$ protein appeared to be affected by $\mathrm{ACTH}_{1-24}$ (35). Additionally, hormone-sensitive protein phosphorylation in brain membranes in a low molecular weight range $(10-20 \mathrm{~K})$ has also been reported $(6,36)$.

In the postmitochondrial brainstem preparation both cyclic AMP and cyclic GMP enhanced phosphorylation of six phosphoprotein bands (50, $51,54,58,73$, and $78 \mathrm{~K})$. However, the cyclic nucleotide-dependent protein kinases apparently are ten times more sensitive to cyclic AMP $\left(10^{-5}\right.$ M) than to cyclic GMP $\left(10^{-4} \mathrm{M}\right.$, Figure 4$)$. In cell-free systems from brain and reticulocytes, stimulation of protein kinases by cyclic AMP at concentrations of $10^{-5}$ to $10^{-7} \mathrm{M}$ may be reproduced by $10-100$ times higher concentrations of cyclic GMP (37-39). A possible explanation would be that cyclic GMP may act as a poor stimulator for the responsible cyclic AMP-dependent protein kinase (40).

Although cyclic AMP may play a role as second messenger in the central nervous system for N-terminal fragments of ACTH (8), in the present investigation no evidence was provided for a cyclic AMP-depdendent kinase control of the peptide-sensitive phosphorylation. In general, different proteins were involved and, for the phosphoprotein which was sensitive to both agents $(50 \mathrm{~K})$, the effects were in opposite directions. Also, Roberts and Ashby (17) reported that phosphorylation of cerebral ribosomal proteins other than S6 $(32 \mathrm{~K})$ may be directed by cyclic nucleotide-independent protein kinases. Additionally, the effects of $\mathrm{ACTH}_{1-24}$ on the phosphorylation of proteins of synaptic brain membranes were also cyclic AMP-independent (6). This is in contrast to the periphery, where ACTH as well as cyclic AMP enhanced the phosphorylation of cytoplasmic proteins in adrenal tissue $(14,15,35,41)$. 
In conclusion, $\mathrm{ACTH}$-sensitive protein kinases which are cyclic nucleotide-independent are present in a postmitochondrial supernatant from rat brainstem. GTP may play a crucial role in peptide-sensitive phosphorylation of postmitochondrial proteins.

\section{ACKNOWLEDGMENTS}

The authors are greatly indebted to Dr. H. Zwiers for introducing them into the techniques of phosphorylation and separation and to Mrs. H. Frankena for her help with the finishing touches. This research was supported by FUNGO grant 13-31-43 of the Netherlands Organization for the Advancement of Pure Research.

\section{REFERENCES}

1. Schotman, P., Reith, M. E. A., vanWimersma Greidanus, Tu. B., Gispen, W. H. and DE WIED, D. 1976. Hypothalamic and pituitary peptide hormones and the central nervous system. Chapter 9, pages 309-344, in GisPEN, W. H. (ed.), Molecular and Functional Neurobiology, Elsevier Scientific Publishing Company, Amsterdam.

2. Gispen, W. H., and Schotman, P. 1976. ACTH and brain RNA: Changes in content and labelling of RNA in rat brain stem. Neuroendocrinology 21:97-110.

3. Reith, M. E. A., Schotman, P., and Gispen, W. H. 1977. Pituitary peptides and brain protein synthesis. Pages 383-398, in Roberts, J., LaJtha, A., and GisPen, W. H. (eds.), Mechanisms, Regulation and Special function of Protein Synthesis in the Brain, Elsevier/ North-Holland, Biomedical Press, Amsterdam.

4. DE WIED, D., and GiSPEN, W. H. 1977. Behavioral effects of peptides. Chapter 14, pages 397-448, in Gainer, H. (ed.), Peptides in Neurobiology, Plenum Press, New York.

5. Schotman, P., van Heuven-Nolsen, D., and Gispen, W. H. 1980. Protein synthesis in a cell-free system from rat brain sensitive to ACTH-like peptides. J. Neurochem. 34:1661-1670.

6. Zwiers, H., Veldhuis, H. D., Schotman, P., and Gispen, W. H. 1976. ACTH, cyclic nucleotides and brain protein phosphorylation in vitro. Neurochem. Res. 1:669-677.

7. Zwiers, H., Wiegant, V. M., Schotman, P., and Gispen, W. H. 1978. ACTH-induced inhibition of endogenous rat brain protein phosphorylation in vitro: Structure activity. Neurochem. Res. 3:455-463.

8. Wiegant, V. M., Dunn, A. J., Schotman, P. and Gispen, W. H. 1979. ACTH-like neurotropic peptides: Possible regulators of rat brain cyclic AMP. Brain Res. 168:565-584.

9. Traugh, J. A., Mumby, M., and Traut, R. R. 1973. Phosphorylation of ribosomal proteins by substrate specific protein kinases from rabbit reticulocytes. Proc. Natl. Acad. Sci. U.S.A. 70:373-376.

10. Cawthon, M. L., Bitte, L. F., Krystosek, A., and Kabat, D. 1974. Effect of cyclic adenosine $3^{\prime}: 5^{\prime}$-monophosphate on ribosomal protein phosphorylation in reticulocytes. J. Biol. Chem. 249:275-278.

11. Traugh, J. A., and Porter, G. G. 1976. A comparison of ribosomal proteins from rabbit reticulocytes phosphorylated in situ and in vitro. Biochemistry 15:610-616.

12. Gressner, A. M., and Wool, I. G. 1976. Influence of glucagon and cyclic adenosine $3^{\prime}: 5^{\prime}$-monophosphate on the phosphorylation of rat liver ribosomal protein S6. J. Biol. Chem. 251:1500-1504. 
13. Loeb, J. E., and Blat, C. Phosphorylation of some rat liver ribosomal proteins and its activation by cyclic AMP. FEBS Lett. 10:105-108.

14. Walton, G. M., and Gill, G. N. 1973. Adenosine 3',5'-monophosphate and protein kinase dependent phosphorylation of ribosomal protein. Biochemistry 12:2604-2611.

15. Walton, G. M., Gill, G. N., Abrass, I. B., and Garren, L. D. 1971. Phosphorylation of ribosome-associated protein by an adenosine $3^{\prime}: 5^{\prime}$-cyclic monophosphate-dependent protein kinase: Location of the microsomal receptor and protein kinase. Proc. Natl. Acad. Sci. U.S.A. 68:880-884.

16. Ashby, C. D., and Roberts, S. 1975. Phosphorylation of ribosomal proteins in rat cerebral cortex in vitro. J. Biol. Chem. 250:2546-2555.

17. Roberts, S., and Ashby, C. D. Ribosomal protein phosphorylation in rat cerebral cortex in vitro. Influence of cyclic adenosine 3':5'-monophosphate. J. Biol. Chem. 253:288-296.

18. Roberts, S., and Morelos, B. S. 1979. Phosphorylation of multiple proteins of both ribosomal subunits in rat cerebral cortex in vivo. Effect of adenosine $3^{\prime}: 5^{\prime}$-cyclic monophosphate. Biochem. J. 184:233-244.

19. ОсноA, S. 1977. Initiation of protein synthesis in prokaryotes and eukaryotes. J. Biochem. 81:1-14.

20. Merrick, W. C. 1979. Evidence that a single GTP is used in the formation of $80 \mathrm{~S}$ initiation complexes. J. Biol. Chem. 254:3708-3711.

21. Gispen, W. H., Schotman, P., and de Kloet, E. R. 1972. Brain RNA and hypophysectomy; a topographical study. Neuroendocrinology 9:285-296.

22. Lowry, O. H., Rosebrough, N. J., Farr, A. L., and Randall, R. J. 1951. Protein measurement with the Folin phenol reagent. J. Biol. Chem. 193:265-275.

23. O'Farrell, P. H. 1975. High resolution two-dimensional electrophoresis of proteins. J. Biol. Chem. 250:4007-4021.

24. Routtenberg, A., and Ehrlich, Y. H. 1975. Endogenous phosphorylation of four cerebral cortical membrane proteins: Role of cyclic nucleotides, ATP and divalent cations. Brain Res. 92:415-430.

25. Ueda, T., Maeno, H., and Greengard, P. 1973. Regulation of endogenous phosphorylation of specific proteins in synaptic membrane fractions from rat brain by adenosine $3^{\prime}: 5^{\prime}$-monophosphate. J. Biol. Chem. 248:8295-8305.

26. Wiegant, V. M., Zwiers, H., Schotman, P., and Gispen, W. H. 1978. Endogenous phosphorylation of rat brain synaptosomal plasma membranes in vitro: Some methodological aspects. Neurochem. Res. 3:443-453.

27. Zisapel, N., and Zurgil, N. 1979. Studies of synaptic vesicles in mammalian brain: characterization of highly purified synaptic vesicles from bovine cerebral cortex. Brain Res. 178:297-310.

28. Feit, H., Dutton, G. R., Barondes, S. H., and Shelanski, M. L. 1971. Microtubule protein: Identification in the transport to nerve endings. J. Cell. Biol. 51:138-147.

29. Zisapel, N., LeVI, M., and Gozes, I. 1980. Tubulin, an integral protein of mammalian synaptic vesicle membranes. J. Neurochem. 34:26-32.

30. Hall, M. E., Wilson, D. L., and Stone, G. C. 1978. Changes in synthesis of specific proteins following axotomy: Detection with two-dimensional gel electrophoresis. J. Neurobiol. 9:353-366.

31. Weller, M. 1979. Enzymes which catalyse the phosphorylation of proteins-the protein kinases. Chapter 2, pages 40-45, in LaGnado, J. R. (ed.), Protein Phosphorylation, Page Bros. (Norwich) Limited, Norwich, U. K.

32. Issinger, O. G., Benne, R., Hershey, J. W. B., and Traut, R. R. 1976. Phosphorylation in vitro of eukaryotic initiation factors IF- $E_{2}$ and IF- $E_{3}$ by protein kinases. J. Biol. Chem. 251:6471-6474. 
33. Rubin, C. S., and Rosen, O. M. 1975. Protein phosphorylation. Annu. Rev. Biochem. 44:831-887.

34. Avruch, J., Witters, L. A., Alexander, M. C., and Bush, M. A. 1978. Effects of glucagon and insulin on cytoplasmic protein phosphorylation in hepatocytes. J. Biol. Chem. 253:4754-4761.

35. Podesta, E. J., Milani, A., Steffen, H., and Neher, R. 1979. Adrenocorticotropin $(\mathrm{ACTH})$ induces phosphorylation of a cytoplasmic protein in intact isolated adrenocortical cells. Proc. Natl. Acad. Sci. U.S.A. 76:5187-5191.

36. Ehrlich, Y. H., Davis, L. G., Keen, P., and Brunngraber, E. G. 1980. Endorphinregulated protein phosphorylation in brain membranes. Life Sci. 26:1765-1772.

37. Miyamoto, E., Kuo, J. F., and Greengard, P. 1969. Cyclic nucleotide dependent protein kinases. J. Biol. Chem. 244:6395-6402.

38. TAO, M., Salas, M. L., and Lipmann, F. 1970. Mechanism of activation by adenosine $3^{\prime}: 5^{\prime}$-cyclic monophosphate of a protein phosphokinase from rabbit reticulocytes. Proc. Natl. Acad. Sci. U.S.A. 67:403-414.

39. Kuo, J. F., and Greengard, P. 1969. Cyclic nucleotide-dependent protein kinases, IV. Widespread occurrence of adenosine $3^{\prime}, 5^{\prime}$-monophosphate-dependent protein kinase in various tissues and phyla of the animal kingdom. Proc. Natl. Acad. Sci. U.S.A. 64:1349-1355.

40. Hixson, C. S., and KreBs, E. G. 1980. Characterization of a cyclic AMP-binding protein from baker's yeast. Identification as a regulatory subunit of cyclic AMP-dependent protein-kinase. J. Biol. Chem. 255:2137-2145.

41. Roos, B. A. 1973. ACTH and cAMP stimulation of adrenal ribosomal protein phosphorylation. Endocrinology 93:1287-1293. 